\title{
Jamaica and Research in Sickle Cell Disease
}

\author{
GR Serjeant, BE Serjeant
}

\begin{abstract}
Many developments have occurred in sickle cell disease and care over the last 50 years in Jamaica. The clinic population grew from 50-60 in the mid-1960s to 5500 in late 1999. During this period, the number of staff serving sickle cell patients increased from 2 to 28 , comprising physicians, paediatricians, nurses, laboratory technologists, social workers, computer staff and statisticians. The physical facilities have improved greatly, and data management has evolved from the typewritten long narrow paper strips in the late 1960s to sophisticated electronic patient management systems. The many physical resources and the superb opportunities of an 'island laboratory' have provided a unique basis for clinical research into the disease.
\end{abstract}

Keywords: Jamaica, sickle cell disease

\section{Jamaica y la investigación de la enfermedad de células falciformes}

GR Serjeant, BE Serjeant

\section{RESUMEN}

En los últimos 50 años se han producido múltiples desarrollos en torno a la enfermedad de células falciformes y su atención en Jamaica. La población clínica, que a mediados de la década de 1960 era de 50-60, ha crecido a 5500 en las postrimerías de 1999. El personal que presta servicios a pacientes sicklémicos, ha aumentado de 2 a 28 trabajadores, incluyendo a médicos, pediatras, enfermeras, técnicos de laboratorio, trabajadores sociales, personal de computación, y estadísticos. Las instalaciones han mejorado considerablemente, y el manejo de datos de los pacientes, que a finales de la década de los 60 consistía en largas tiras de papel mecanografiadas, ha sido transformado en un sofisticado sistema electrónico de administración de pacientes. La multitud de recursos fisicos y las magnificas oportunidades de una 'isla-laboratorio' han proporcionado una base única para la investigación clínica de la enfermedad.

Palabras clave: Jamaica, enfermedad de células falciformes

From: Sickle Cell Trust (Jamaica), Kingston, Jamaica, West Indies.

Correspondence: Professor G Serjeant, Sickle Cell Trust (Jamaica), 14 Milverton Crescent, Kingston 6, Jamaica, West Indies. Email: grserjeant@gmail.com

Informed consent was obtained where necessary.

\section{EARLY DAYS OF THE UNIVERSITY COL-} LEGE HOSPITAL OF THE WEST INDIES

The story of sickle cell disease in the Caribbean is intimately related to the development of the then University College of the West Indies (UCWI), now University Hospital of the West Indies (UHWI). Following the Second World War, Sir James Irvine chaired a Committee 
for Higher Education in the Colonies, which visited Jamaica in 1945 and recommended the establishment of a university starting with a medical faculty because of the shortage of medical practitioners in the area. The UCWI, affiliated to the University of London, was established in October 1948 with the enrolment of the first medical students who had to gain clinical experience in Kingston Public Hospital while awaiting the building of the UHWI on grounds adjacent to the UCWI on the outskirts of Kingston. The foundation stone for the new hospital was laid by the Earl of Athlone, the husband of the first Chancellor of The University of the West Indies (UWI), Princess Alice, but it was not until 1952 that the building was finally available. It was opened officially by Sir Hugh Foot, Governor of Jamaica, on January 15, 1952 and three days later Winston Churchill unveiled a plaque recognizing the contribution of the British Government.

\section{EARLY RESEARCH ON SICKLE CELL}

As staff were appointed to the laboratory and clinical services, interest in sickle cell disease started almost immediately. The first published work in 1953-54 was by Derrick Jelliffe $(1,2)$, who had recently moved from the University Hospital in Ibadan, Nigeria, to the Department of Medicine at UWI, Mona, Jamaica. He surveyed 2116 Jamaican school children of different racial origins with the rather primitive Scriver-Waugh technique, deoxygenating red cells in a sealed chamber, and found positive tests in $5.7 \%$ of 'average Jamaican children of African ancestry'. The early interest was highlighted by a Sickle Cell Symposium on May 28, 1954, chaired by Professor Eric Cruickshank, which addressed the prevalence of the trait, the clinical features, bone and radiological changes and the pathology (3). The arrival of John MacIver and Lodewijk Went in the Department of Pathology led to a fruitful collaboration which introduced haemoglobin electrophoresis enabling the distinction of different genotypes of sickle cell disease (4-6), the characteristics of sickle cell-beta thalassaemia (7-9), a rare variant haemoglobin (10) and one of the first descriptions of hereditary persistence of fetal haemoglobin $[\mathrm{HbF}]$ (11). Clinical contributions were also made on megaloblastic change (12) and the aplastic crisis (13), the bone changes by John Golding $(14,15)$ and outcome of pregnancy by Mavis Anderson $(16,17)$.

\section{ARRIVAL OF PAUL MILNER}

The next major event was the arrival of Paul Milner and his wife Ann in the Department of Pathology. He quickly took an interest in sickle cell disease which was further stimulated by a visit from Professor Hermann Lehmann, of the British Medical Research Council (MRC) Abnormal Haemoglobin Unit in Cambridge, England. At that stage, it had become clear from the increasing numbers of patients and the research potential that a dedicated Sickle Cell Clinic was justified and this took place every Friday morning in the 'Gynaecology Clinic'. The UHWI agreed that there would be no charge as it was a research clinic and since Paul Milner was a laboratorytrained haematologist, he requested clinical assistance from the senior registrar to Eric Cruickshank, Knox Hagley. When this post became available in August 1966, Graham Serjeant arrived from England and assisted in the Sickle Cell Clinic, which in those days saw 10 to 15 patients each Friday morning. Meanwhile, Ann Milner, a secretary by training, recorded the haematology and clinical features of individual patients on long strips of paper which were affixed to sheets of cardboard as a filing system. There then began a collaboration of Paul Milner with Graham Serjeant involving Beryl Serjeant, a laboratory technologist, who assisted Paul in the development of laboratory techniques. In early 1967, while touring the Caribbean, Peter Williams, secretary of the Wellcome Trust, arrived in Jamaica looking for research projects and Paul Milner and Graham Serjeant applied and were awarded a grant of $£ 17000$ over two years. This provided Paul Milner with an early Coulter counter (haematology analyser) for the laboratory, paid the salaries of Graham and Beryl Serjeant and provided a Volkswagen minibus as a mobile clinical unit with the rear seats replaced by an examination couch and worktable.

Graham Serjeant was designated a Wellcome Research Fellow in the Department of Medicine and worked from Room 3 of the Rippel Building, a medical research facility at the UHWI. Although officially the Sickle Cell Clinic still operated only on Friday mornings, the patients soon learnt that medical help was available in Room 3 of the Rippel Building which quickly became a daily clinic, even functioning on Saturday mornings. This unofficial clinical facility was invaluable, with one end of a large laboratory being used for patient care, the other end for blood tests and haematology and a side bench for the analysis of newborn screening samples from Victoria Jubilee Hospital (VJH). Painful crises proved to be a problem in management, 
and in preference to languishing in the Accident and Emergency Department, Room 4 of the Rippel Building became a day care centre with foam mattresses on the laboratory benches. Although not ideal and far from being currently acceptable, this allowed continuity of patient care until the dedicated Sickle Cell Clinic became available.

The mobile clinical unit (Fig. 1) proved invaluable, and the first project was to locate patients with SS disease who used to attend the Sickle Cell Clinic but had not been seen for 10 years and were then aged over 30 years.

According to the textbooks of that period, patients rarely survived to adult life and so it was natural to assume that they had died. Out of 50 such patients, 5 were found to have died, 5 had emigrated, 17 could not be traced, but $23(46 \%)$ were alive and well and had defaulted from clinic follow-up because they were clinically well. This realization that many Jamaican patients survived to later adult life and actually improved clinically was totally unexpected and, when published (18), led to the assumption by others that either the patients did not have the disease but had the trait or the disease in Jamaica was different.

The reality, of course, was that we were beginning to observe the true natural history of the disease and the assumption of universal severity derived from observations elsewhere resulted from the symptomatic bias in focussing on severely affected patients. This was amply demonstrated following the National Sickle Cell Anemia Control Act in the United States of America [USA] (19) which promoted population screening and led to the detection of unsuspected cases of SS disease on active military service. This was yet another example of the suitability of Jamaica for clinical studies allowing long-term follow-up of patients, and attitudes had changed so much that the description of 102 patients with SS disease aged over 60 years in Jamaica (20) caused little surprise.

\section{TAKING THE CLINICS TO THE PATIENTS}

The observation that mildly affected patients defaulted from clinical care confirmed the impression of a symptomatic bias in clinic attendees. This led to an approach to reduce this bias by taking clinical care to the patients, and Sickle Cell Clinics were established attached to six country hospitals at Morant Bay, Annotto Bay, St Ann's Bay, Mandeville, Black River and Montego Bay, so that no patient had to travel more than about 30 miles. In Montego Bay, the clinic was conducted in a wooden cottage, labelled 'The Specialist Clinic', on the grounds of the old St James Hospital (Fig. 2). These were conducted every six weeks between 1967 and 1971 by Graham and Beryl Serjeant and saw large numbers of patients, especially at Black River and Montego Bay in the west of Jamaica. Bus fares were provided, if necessary, and patients failing to attend were visited in their homes (Fig. 3).

All went well and it was assumed that the bias of symptomatic patients had been removed until one day

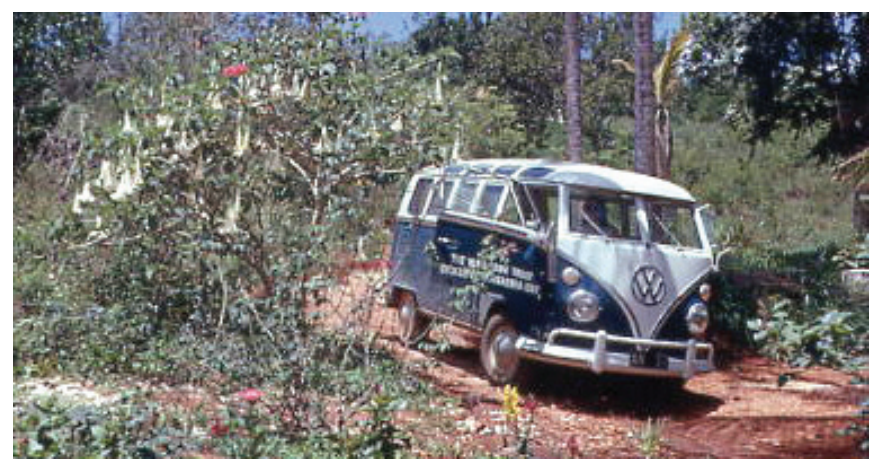

Fig. 1: The mobile clinical unit, at Red Bank, St Elizabeth.

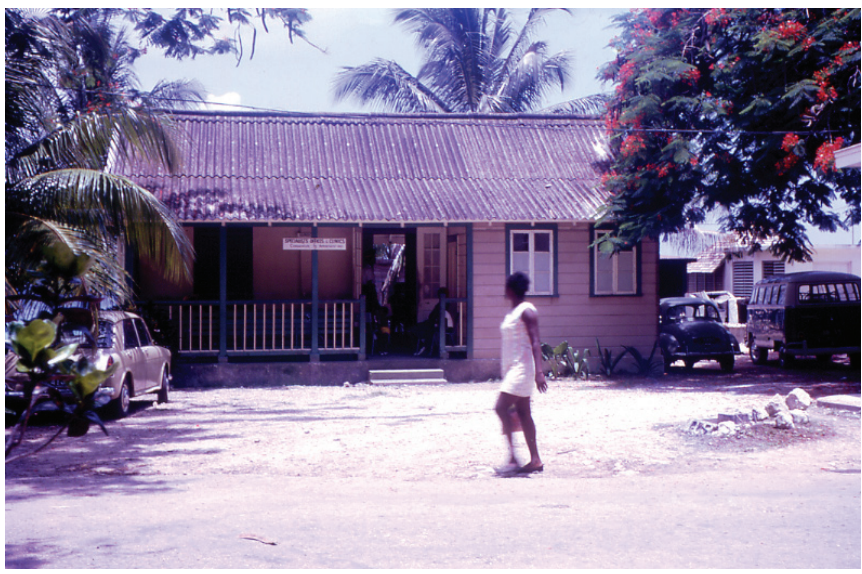

Fig. 2: Outreach clinic at St James Hospital.

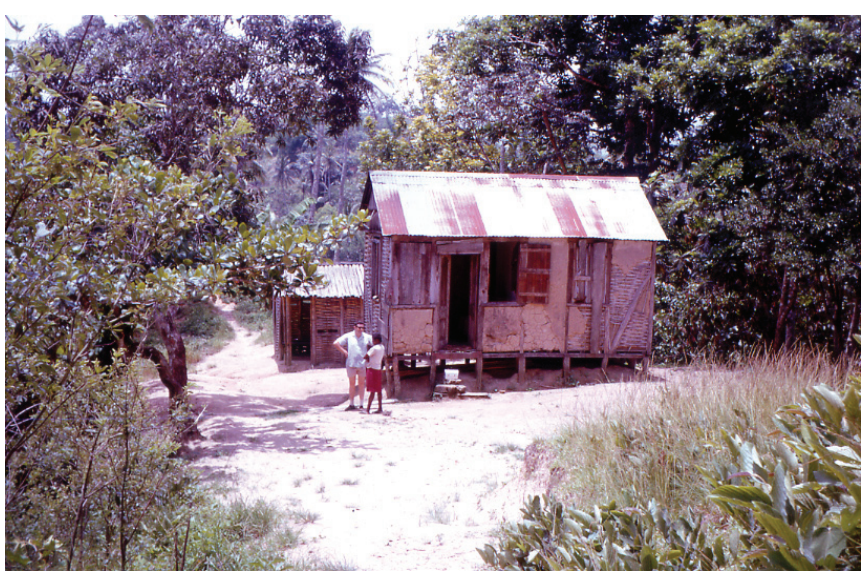

Fig. 3: Home visit. 
on a cottage doorstep in the parish of St James behind Montego Bay. While visiting a family with sickle cellbeta $^{\circ}$ thalassaemia in which the patient aged 10 years was running a severe clinical course, she was photographed alongside her 'normal' sister aged eight years to demonstrate the effects of sickle cell disease on growth, body build and affect (Fig. 4). However, a blood test on the 'normal' sister showed that she also had sickle cell-beta ${ }^{\circ}$ thalassaemia. Therefore, although we had reduced the bias in our observations, we were still unaware of mildly affected cases. To document the disease properly, a population had to be defined without any symptomatic bias and that required newborn screening.

THE FIRST INTERNATIONAL SICKLE CELL CONFERENCE

This took place at UWI on January 8-10, 1969 (21, 22) and was a rather amateur but enthusiastic affair

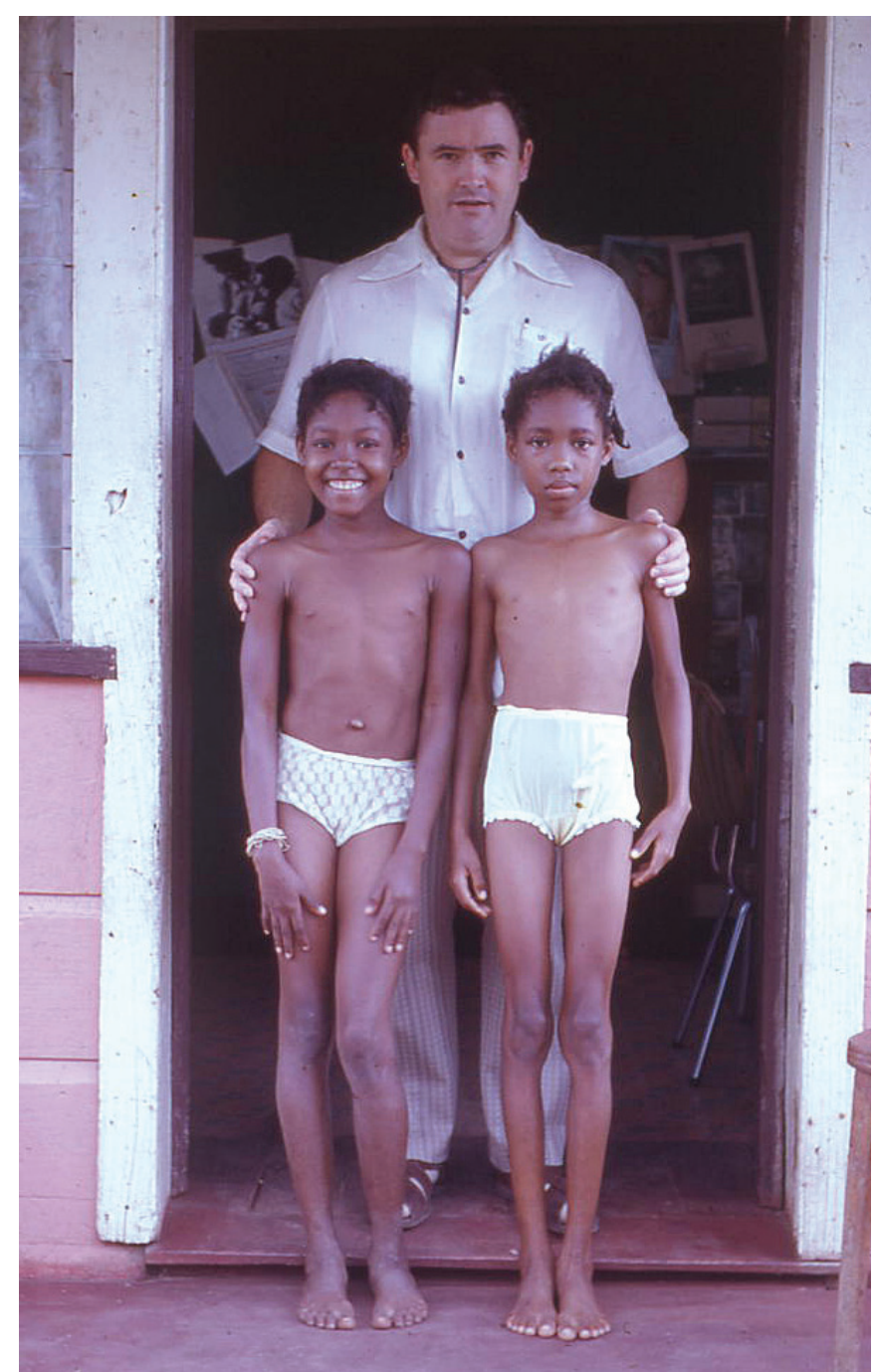

Fig. 4: Two sisters aged 10 years (right) and 8 years (asymptomatic), both with sickle cell-beta ${ }^{\circ}$ thalassaemia. involving most of the small number of people working in sickle cell disease in the days prior to the stimulus of the National Sickle Cell Anemia Control Act in the USA (19). Money was raised locally with excellent support from the bauxite companies which allowed us to offer half of the airfare, and accommodation was provided by colleagues on campus. Attendees from abroad included John MacIver, Richard Huntsman, Ernst Huehns and Hermann Lehmann from the United Kingdom (UK), Lodewjik Went from Holland, Roger Lewis from Ghana, A van der Saar from Curacao, Lemuel Diggs, Howard Pearson, Charles August, William Mentzer, John Bertles and Wallace Jensen from the USA, Wilfrid Dos Santos from Barbados, and many local colleagues from Pathology, Medicine, Paediatrics, Obstetrics, Orthopaedics, Accident and Emergency and the Tropical Metabolism Research Unit (Fig. 5).

\section{INTERLUDES IN MEMPHIS, USA, AND CAM- BRIDGE, ENGLAND}

In 1969, the Wellcome Trust grant was renewed for a further three years. However, in May 1971, Graham and Beryl Serjeant went for three months to the Sickle Cell Center in Memphis, Tennessee, run by Dr Lemuel Diggs (one of the grand old men of sickle cell disease who had been publishing on the condition since 1932), and then to Cambridge to work with Professor Hermann Lehmann in the British MRC Abnormal Haemoglobin Unit in the Department of Biochemistry in Cambridge, England, intending to pursue a $\mathrm{PhD}$ over three years. However, after the first three months sitting in a laboratory in Cambridge while the clinical studies in Jamaica had ceased, it became clear that this was the wrong decision. Negotiations with the British MRC led to the decision to return to Jamaica in November 1972 to start the Jamaican Cohort Study of Sickle Cell Disease.

\section{OTHER DEVELOPMENTS IN THE 1970s}

Returning as a staff member to the then British MRC Epidemiology Research Unit (ERU) on the UWI, Mona Campus, the initial work was dominated by several themes. A chance meeting with Richard Huntsman from St Thomas' Hospital, London, led to a link with Patrick Condon, an Irish ophthalmologist, who during the course of several visits to Jamaica laid the foundation for the work on sickle cell eye disease (23-30). A member of the ERU, Michael Ashcroft, conducted studies on body build in sickle cell disease (31-35), and the Tropical Metabolism Research Unit's George Alleyne and colleagues addressed acid-base issues in the disease 


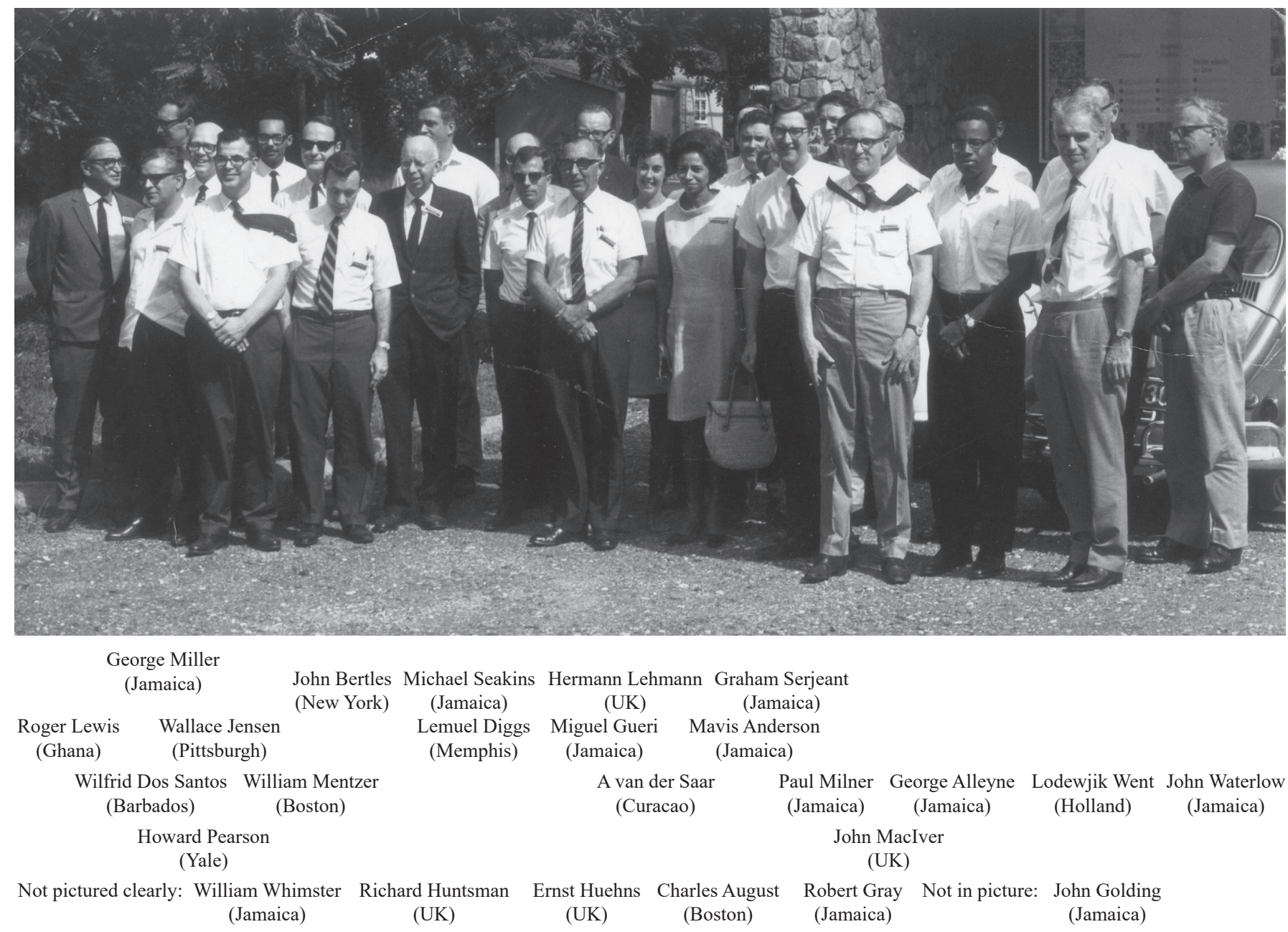

Fig. 5: First International Sickle Cell Conference, January 8-10, 1969.

(36-42). A meeting with Sir Howard Middlemiss, Professor of Radiology at Bristol, whose postgraduate students were seconded to Mona led to a series of radiological contributions (43-46), and the Departments of Medicine, Pathology and Paediatrics studied renal complications and the general pathology of the disease (47-52).

\section{THE JAMAICAN COHORT STUDY OF SICKLE CELL DISEASE}

The ability to locate many defaulting but surviving patients in Jamaica raised issues on the variability of clinical course in the disease, and it was becoming clear that although the disease resulted from a single primary gene defect, there was a wide and unexplained variability in clinical course. To understand factors contributing to this variability, it was necessary to define a study population without any symptomatic selection. The best option was at birth, but at that time there were concerns on the reliability of newborn diagnosis in the presence of high levels of $\mathrm{HbF}$. These were largely resolved by the work of Rosie Schneider in Texas, and by combining screening methods using cellulose acetate followed by confirmation of variant bands by agar gel, Beryl Serjeant evolved techniques which reliably made the diagnosis (53).

The stage was set to screen a newborn population, and in collaboration with Leslie Williams, senior medical officer at VJH, screening commenced on June 25, 1973 (Fig. 6). Once again, Jamaica led the world as many researchers still claimed at that time that the diagnosis of sickle cell disease could not be made at birth. The midwives of VJH were superb, and over the next eight and a half years, ending on December 28, 1981, a total of 100000 non-operative deliveries were screened with the detection of 550 babies with forms of sickle cell disease (54). The first 125 patients with an SS phenotype were matched by age and gender to two controls with normal AA phenotype providing 250 controls, and the entire 800 subjects have been followed up over 


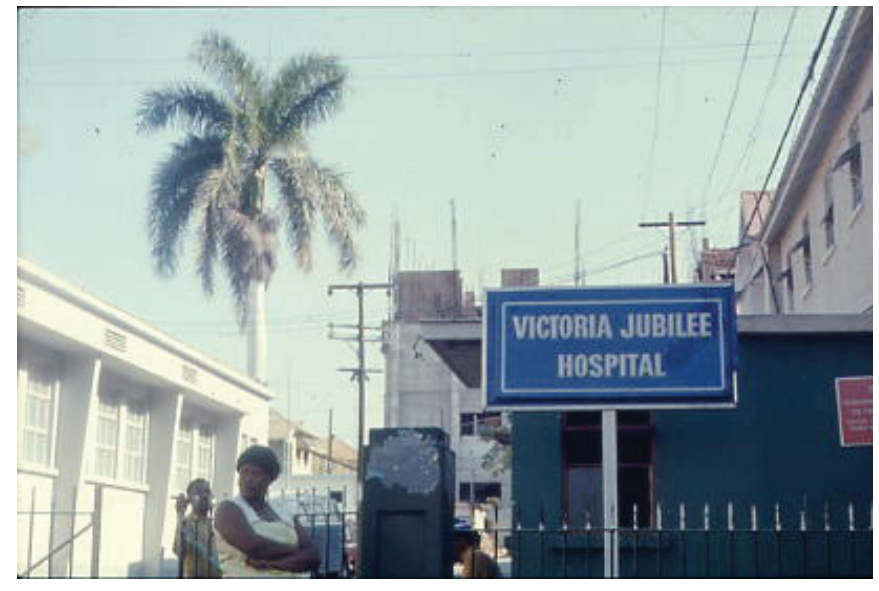

Fig. 6: The old Victoria Jubilee Hospital (left) with the new hospital under construction.

periods of up to 43 years. As the children aged, their clinical course was documented, complications defined, and interventions developed for their prevention where possible. Major developments included pneumococcal prophylaxis (55), teaching mothers to reduce mortality from acute splenic sequestration by detection at home (56), the role of parvovirus in the aplastic crisis (57-60), treatment trials for chronic leg ulcers (61-65), the natural history of priapism (66-68), enuresis (69-71), the outcome of pregnancy (72-79), precipitants and features of the painful crisis (80-84), evolution of haematological change (85-91), the causes of death $(92,93)$ and many others.

Jamaica has been fortunate in collaboration with groups abroad such as David Weatherall and Douglas Higgs in Oxford and with Johns Hopkins Hospital, especially George Dover, which have increased the understanding of molecular changes modifying expression of the disease (94-107). The evolution of ocular pathology in Cohort subjects was carefully documented from 1980 to 2000 by Alan Bird from Moorfields Eye Hospital in London who, with Mrs Sarah Bird, led a team of four to five ophthalmologists who volunteered their services for two to three weeks each year. With measurements of visual acuity, dilatation, retinal drawings and fluorescein angiography, these studies accumulated a unique database on eye complications of sickle cell disease (108-112).

While the Cohort subjects were waiting to dilate, Tom Walker, a radiologist from the Royal Berkshire Hospital, Reading, UK, also volunteered to do annual ultrasounds for gallstones, renal and splenic features (113-118). The Cohort Study has also taught us much about the clinical variability, the determinants of that variability, the role of genetic factors such as alpha thalassaemia, the persistence of $\mathrm{HbF}$ and also of the environment, of skin cooling and the painful crisis, and the milder clinical course associated with improved socio-economic status. The success of the Cohort Study was made possible by the generous and sustained funding from the British MRC, the clinic facilities developed by the Sickle Cell Trust, but above all by the co-operation and enthusiasm of the Cohort patients and their parents.

\section{GEOGRAPHIC COMPARISONS}

The development of models of care appropriate to societies with high frequencies of variant haemoglobins and limited resources has made the Jamaican experience of value to other societies. As a result, the Jamaican experience has been sought by colleagues in Brazil, Greece (119), Turkey, Saudi Arabia (120-122), Bahrain, Uganda $(123,124)$ and India $(125-129)$, and has also contributed to the development of sickle cell care in more developed countries such as the USA and the UK. These collaborations have also provided research opportunities for learning about the variability of sickle cell disease and the determinants of this variability.

\section{SICKLE CELL TRUST (JAMAICA)}

The British MRC funded the scientific research programmes of the MRC Laboratories, but additional demands had to be met from other sources. This was the background to the formation of the Sickle Cell Trust (Jamaica) as a locally registered charity in 1986 with Graham Serjeant (Chairman), Karlene Mason (Secretary) and 11 Board Members. The Trust received superb support from the private sector in Jamaica and internationally which ensured success of the following projects. The first appeal for US\$50 000 to purchase a diagnostic ultrasound instrument (Fig. 7) for studies on gallstones and renal assessment was completed within two months following a major donation from the National Commercial Bank.

The next project was the raising of $£ 100000$ for the construction of a dedicated Sickle Cell Clinic adjacent to the MRC offices on the UWI, Mona Campus. This provided a laboratory, four consulting rooms, treatment rooms and an eight-bed day care centre and was officially opened in August 1988. Since the clinic was to be on the Campus about half a mile from that in the Rippel Building, it was necessary to provide a shuttle service, in a minibus donated by the Dutch Government (Fig. 8) which operated from perhaps the world's only Sickle Cell Clinic bus stop (Fig. 9). The dedicated centre 


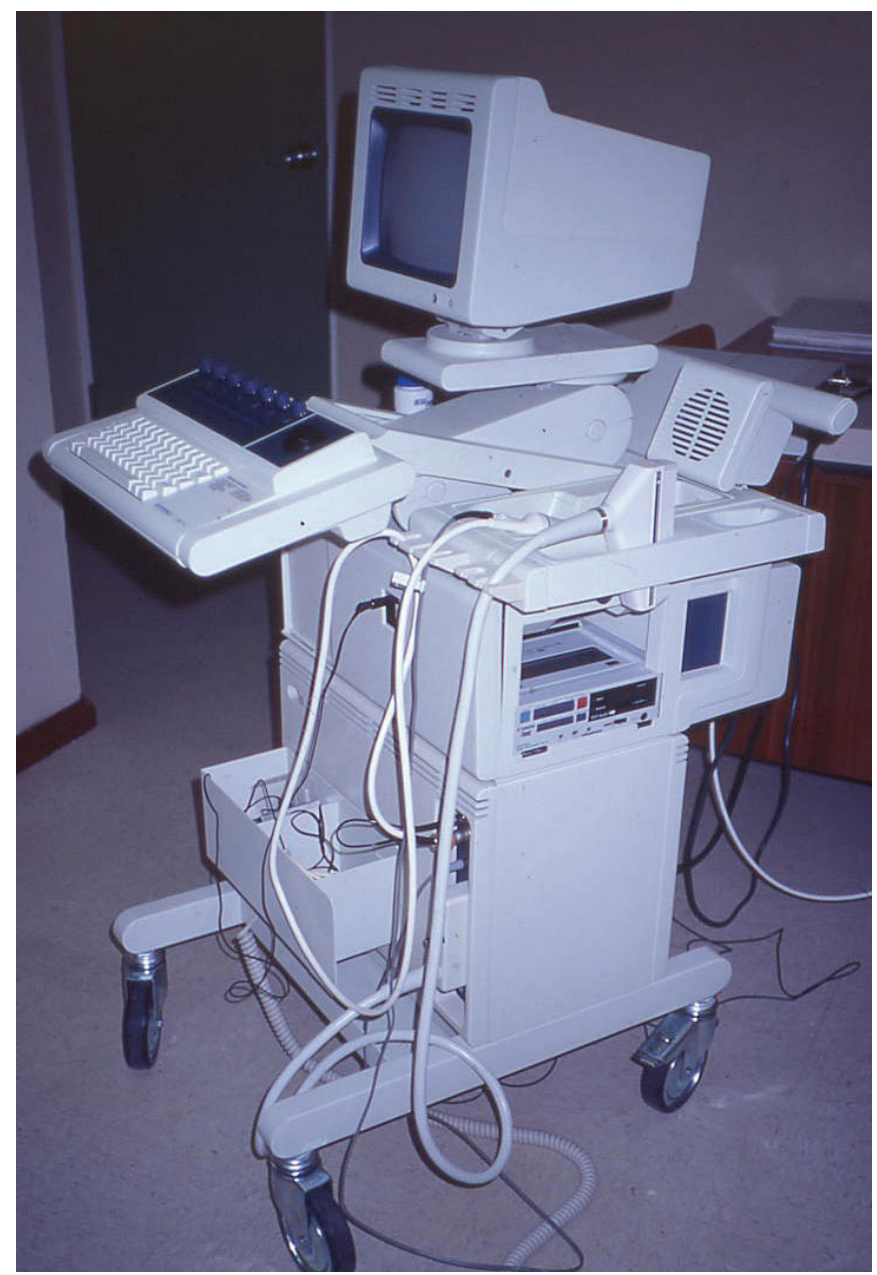

Fig. 7: Diagnostic ultrasound instrument.

provided much better facilities for patient care and the associated research and appeared to have had a profound impact on the features of the disease. Patients were reassured that all staff in the clinic were familiar with sickle cell disease. They saw nurses, doctors and technologists with whom they were already familiar and who already had their records, avoiding the confrontation often encountered in Accident and Emergency departments of hospitals elsewhere. For many patients, this reassurance was a major part of the battle and exemplified by several patients in painful crises who stated that they only had to reach the doors of the Sickle Cell Clinic to start to feel better. In the day care centre, where at busy times of the year, the eight beds may have had to be supplemented by padded benches in the corridor. In the mid-afternoon before the clinic closed, patients were given the option of going home with the same pain-relieving medicines or being admitted to hospital, and over $90 \%$ of patients chose to go home. The clinic became an example of the benefits of holistic care in improving the clinical course of many patients.

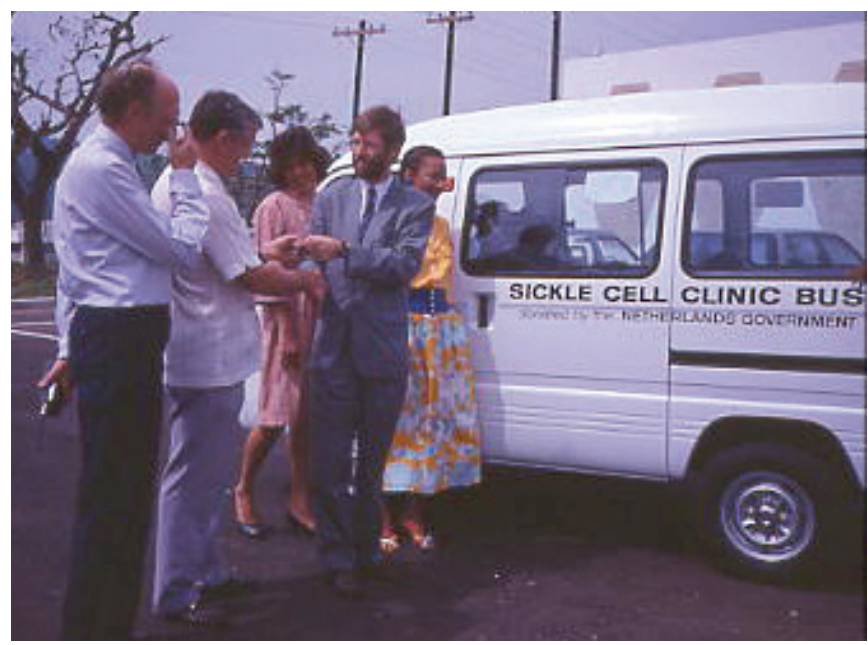

Fig. 8: Shuttle minibus donated by the Dutch Government.

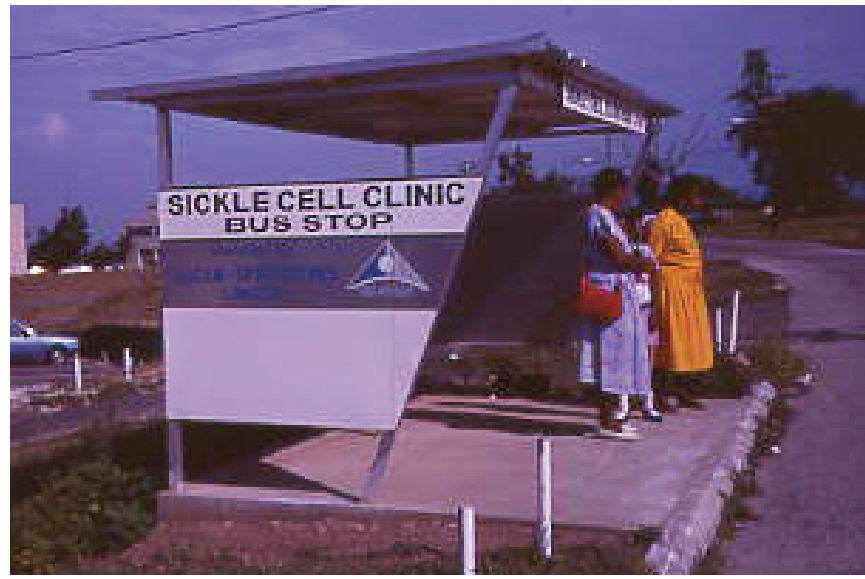

Fig. 9: Sickle Cell Clinic bus stop.

The next project was the building of an Education Centre for Sickle Cell Disease on the roof of the clinic which was funded by a single donation of J\$7 million (£120 000) from the then Telephone Company of Jamaica chaired by Mayer Matalon. The centre opened in 1994 (Fig. 10) and provided an 80-seat seminar room, a laboratory for the Jamaican Government newborn screening programme for sickle cell disease, rooms for presenting and developing educational videos, interactive CD-ROM tutorials, and offices. It was a valuable facility for educational and counselling courses. With the retirement of Graham Serjeant from the MRC in September 1999, these facilities were assumed by UWI, which continues to operate the Sickle Cell Clinic.

Retirement also brought a new phase of the Trust activities, commencing with the organization of illustrated PowerPoint lectures conducted by Karlene Mason to the Fifth and Sixth forms of most of Jamaica's 160 secondary schools and tertiary institutions, eg teacher training schools, nursing schools and community 
colleges, focussing on sickle cell disease, symptoms, complications and genetics. At the end of these presentations, there were questions, but the major request was how students could find out whether they carried variant genes placing them at risk of having a baby with sickle cell disease. The answer was not reassuring as students were told to attend private laboratories where the tests would be expensive and may lack the precision needed for genetic counselling. This programme of public education continued all over Jamaica for eight years (2000-07), and the increasing demand for knowledge of haemoglobin genotype by the students led to the next phase which was the Manchester Project.

\section{THE MANCHESTER PROJECT}

In discussion with the Ministry of Health and Ministry of Education, a project was designed to offer free detection of haemoglobin genotypes to the senior students of 15 secondary schools in the Manchester parish. This was part of a larger project associated with education and counselling to determine whether provision of genotype information would influence their choice of partner and reduce the frequency of births affected by sickle cell disease. From 2008 to 2013, screening of 16636 students in the Fifth and Sixth forms (Fig. 11) found 2432 $(14.6 \%)$ students with variant genes, placing them at risk of having a baby with sickle cell disease. All students were given haemoglobin genotypes on laminated cards, and carriers of variant haemoglobins were offered counselling.

To determine any effect on subsequent reproduction, newborn screening was set up with cord blood samples starting with Mandeville Regional Hospital in 2008 and spreading to involve over 15000 deliveries annually in 12 hospitals in the southern and western regions. The

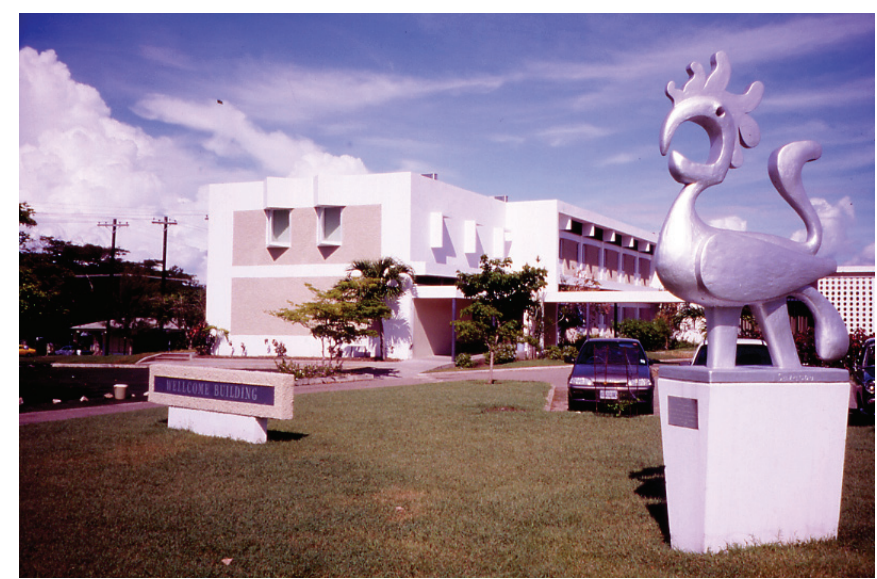

Fig. 10: Combined Sickle Cell Clinic (ground floor) and Education Centre (upper floor). samples were collected on Guthrie cards as blood spots, obtained as the umbilical cord was cut, the samples were dried and then sent to the Central Laboratory in Mandeville. Diagnosis at birth required greater sensitivity to detect low levels of beta chain haemoglobins in the presence of high levels of $\mathrm{HbF}$, and this was most readily achieved by high pressure liquid chromatography (HPLC) in instruments capable of making the diagnosis in three minutes per sample (Fig. 12).

At the end of 2015, an analysis was conducted on 2442 pregnancies to the mothers screened as students failed to show any evidence that the intervention had reduced affected births. Focussing on 898 females with the sickle cell trait, there were five babies with SS disease compared with 5.5 cases predicted from random mating (130). Interviews with the mothers indicated that either their genotype was not mentioned to the boyfriends or the latter declined to be tested. Newborn screening is now well established in the south and west

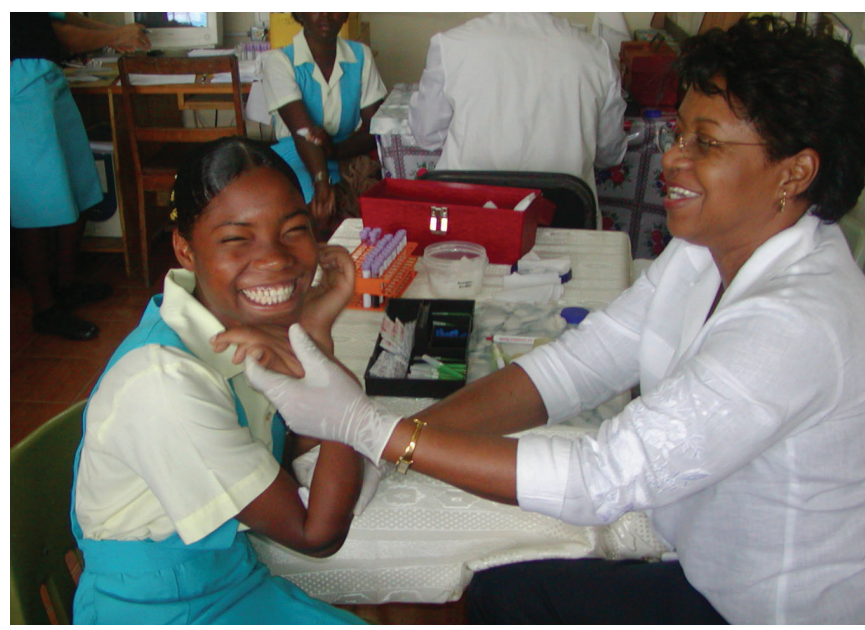

Fig. 11: An enthusiastic student at Christiana High School.

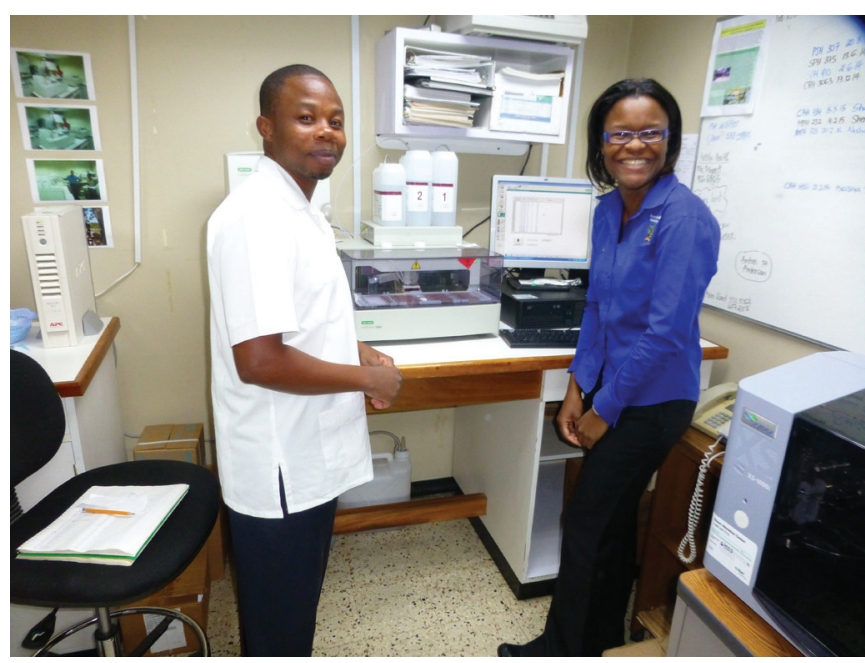

Fig. 12: Staff with the Bio-Rad NBS HPLC instrument. 
of Jamaica and will be continued by the Ministry of Health. Together with the Sickle Cell Unit at UWI which has started screening in the south-east and north-east, the Ministry of Health is finally offering universal screening for sickle cell disease.

\section{CONCLUSION}

Many developments have occurred in sickle cell disease and care over the last 50 years in Jamaica (Fig. 13). The clinic population grew from $50-60$ in the mid-1960s to 5500 in late 1999. During this period, the number of staff serving sickle cell patients increased from 2 to 28 , comprising physicians, paediatricians, nurses, laboratory technologists, social workers, computer staff and statisticians. The physical facilities have improved greatly, and the long thin paper strips with patient data employed by Ann Milner in the late 1960s have evolved into sophisticated electronic patient management systems. The research output now exceeds 500 papers in the peer-reviewed press, and Jamaica continues to teach the world much about sickle cell disease. It has been over 40 years since Jamaica became the first country in the world to have extensive newborn screening, and it is gratifying to know that the Sickle Cell Trust was a stimulus to the final development of universal newborn screening in Jamaica. There have also been many other lessons from this brief review of sickle cell research activity since 1952, and foremost among these are the unique opportunities of an island laboratory for longterm studies of the disease. The work has also benefitted from collaborations with many groups worldwide who have recognized these research opportunities. Finally, it is with gratitude to the willingness and co-operation of many of the patients that so much has been learnt about the disease over the last 64 years.

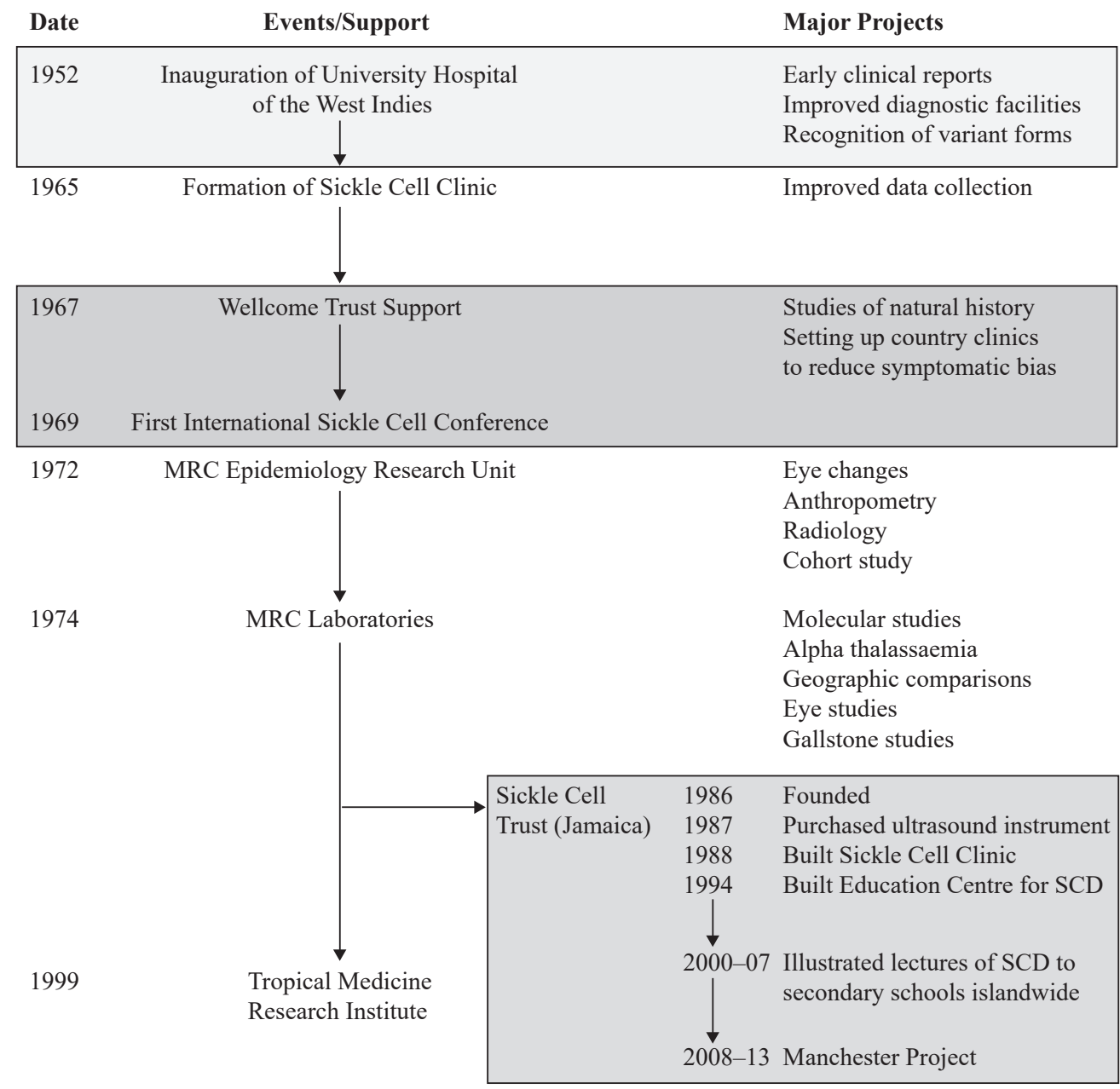

Fig. 13: Timeline of events. 


\section{REFERENCES}

1. Jelliffe DB. Observations on sickle-cell disease in Jamaica. J Trop Med Hyg 1953; 56: 257-61.

2. Jelliffe DB, Stuart KL, Wills VG, Jelliffe EFP. The sickle cell trait in Jamaica. Blood 1954; 9: 144-52.

3. Sickle Cell Anaemia Symposium at the University College of the West Indies. West Indian Med J 1955; 4: 25-37.

4. Went LN, MacIver JE. Investigation of abnormal haemoglobins in Jamaica; a preliminary study. West Indian Med J 1956; 5: 247-55.

5. Went LN. Incidence of abnormal haemoglobins in Jamaica. Nature 1957; 180: 1131-2.

6. MacIver JE, Went LN. Further observations on abnormal haemoglobins in Jamaica. West Indian Med J 1958; 7: 109-22.

7. MacIver JE, Went LN, Cruickshank EK. Sickle cell-thalassemia disease in Jamaica. Blood 1958; 13: 359-66.

8. Went LN, MacIver JE. Sickle-cell anaemia in adults and its differentiation from sickle-cell thalassaemia. Lancet 1958; 2: 824-6.

9. Went LN, MacIver JE. An unusual type of hemoglobinopathy resembling sickle cell-thalassaemia in a Jamaican family. Blood 1958; 13: 559-68.

10. Went LN, MacIver JE. Sickle-cell haemoglobin-J disease. Br Med J 1959; 2: 138-9.

11. MacIver JE, Went LN, Irvine RA. Hereditary persistence of foetal haemoglobin: a family study suggesting allelism of the $\mathrm{F}$ gene to the $\mathrm{S}$ and C haemoglobin genes. Br J Haematol 1961; 7: 373-81.

12. MacIver JE, Went LN. Sickle-cell anaemia complicated by megaloblastic anaemia of infancy. Br Med J 1960; 1: 775-9.

13. MacIver JE, Parker-Williams EJ. The aplastic crisis in sickle-cell anaemia. Lancet 1961; 1: 1086-9.

14. Golding JSR. The bone changes in sickle cell anaemia. Ann Roy Coll Surg England 1956; 19: 296-315.

15. Golding JSR, MacIver JE, Went LN. The bone changes in sickle cell anaemia and its genetic variants. J Bone Jt Surg 1959; 41B: 711-8.

16. Anderson MF, Went LN, MacIver JE, Dixon HG. Sickle-cell disease in pregnancy. Lancet 1960; 2: 516-21.

17. Anderson MF. Haemoglobinopathies in pregnancy. West Indian Med J 1962; 11: 265-74

18. Serjeant GR, Richards R, Barbor PR, Milner PF. Relatively benign sickle-cell anaemia in 60 patients aged over 30 in the West Indies. Br Med J 1968; 3: 86-91.

19. National Sickle Cell Anemia Control Act, Public Law 92-294, 92 ${ }^{\text {nd }}$ Congress, S. 2676, May 16, 1972

20. Serjeant GR, Serjeant BE, Mason KP, Hambleton IR, Fisher C, Higgs DR. The changing face of homozygous sickle cell disease: 102 patients over the age of 60 years. Int J Lab Hematol 2009; 31: 585-96.

21. Sickle cell anaemia. A report of the First International Symposium held at The University of the West Indies, Jamaica, January 8-10, 1969. J Trop Pediatr (1967), 1969; 15: 50-3.

22. Abstracts from the First International Sickle Cell Anaemia Conference. Blood 1969; 34: 727-37.

23. Condon PI, Serjeant GR. Ocular findings in homozygous sickle cell anemia in Jamaica. Am J Ophthalmol 1972; 73: 533-43.

24. Serjeant GR, Serjeant BE, Condon PI. The conjunctival sign in sickle cell anemia. A relationship with irreversibly sickled cells. JAMA 1972; 219: $1428-31$.

25. Condon PI, Serjeant GR. Ocular findings in sickle cell thalassemia in Jamaica. Am J Ophthalmol 1972; 74: 1105-9.

26. Condon PI, Serjeant GR. Ocular findings in hemoglobin SC disease in Jamaica. Am J Ophthalmol 1972; 74: 921-31.

27. Condon PI, Gray R, Serjeant GR. Ocular findings in children with sickle cell haemoglobin C disease in Jamaica. Br J Ophthalmol 1974; 58: 644-9.

28. Condon PI, Serjeant GR. The progression of sickle cell eye disease in Jamaica. Doc Ophthalmol 1975; 39: 203-10.

29. Condon PI, Serjeant GR. Ocular findings of elderly cases of homozygous sickle-cell disease in Jamaica. Br J Ophthalmol 1976; 60: 361-4.

30. Condon PI, Serjeant GR. Ocular findings in sickle cell-haemoglobin O Arab disease. Br J Ophthalmol 1979; 63: 839-41.
31. Ashcroft MT, Miall WE, Milner PF. A comparison between the characteristics of Jamaican adults with normal hemoglobin and those with sickle cell trait. Am J Epidemiol 1969; 90: 236-43.

32. Ashcroft MT, Serjeant GR, Desai P. Heights, weights, and skeletal age of Jamaican adolescents with sickle cell anaemia. Arch Dis Child 1972; 47: 519-24

33. Ashcroft MT, Serjeant GR. Body habitus of Jamaican adults with sickle cell anemia. South Med J 1972; 65: 579-82.

34. Ashcroft MT, Desai P. Mortality and morbidity in Jamaican adults with sickle-cell trait and with normal haemoglobin followed up for twelve years. Lancet 1976; 2: 784-6.

35. Ashcroft MT, Desai P, Richardson SA, Serjeant GR. Growth, behaviour, and educational achievement of Jamaican children with sickle-cell trait. Br Med J 1976; 1: 1371-3.

36. Kong HH, Alleyne GA. Defect in urinary acidification in adults with sickle-cell anaemia. Lancet 1968; 2: 954-5.

37. Kong HH, Alleyne GA. Acid-base status of adults with sickle-cell anaemia. Br Med J 1969; 3: 271-3.

38. Kong HH, Alleyne GA. Studies on acid excretion in adults with sicklecell anaemia. Clin Sci 1971; 41: 505-18.

39. Alleyne GA. The kidney in sickle cell anemia. Kidney Int 1975; 7: $371-9$.

40. Wilson WA, Alleyne GA. Renal function during painful sickle cell crisis. West Indian Med J 1975; 24: 84-9.

41. Wilson WA, Alleyne GA. Total body water, extracellular and plasma volume compartments in sickle cell anemia. West Indian Med J 1976 25: $241-50$.

42. Forrester TE, Alleyne GA. Excretion of salt and water by patients with sickle-cell anaemia: effect of a diuretic and solute diuresis. Clin Sci Mol Med 1977; 53: 523-7.

43. Ennis JT, Gueri MC, Serjeant GR. Radiological changes associated with leg ulcers in the tropics. Br J Radiol 1972; 45: 8-14.

44. Serjeant GR, Ennis JT, Middlemiss H. Sickle cell beta thalassaemia in Jamaica. Br J Radiol 1973; 46: 951-9.

45. Ennis JT, Serjeant GR, Middlemiss H. Homozygous sickle cell disease in Jamaica. Br J Radiol 1973; 46: 943-50.

46. Serjeant GR, Ennis JT, Middlemiss H. Haemoglobin SC disease in Jamaica. Br J Radiol 1973; 46: 935-42.

47. Thorburn MJ. The pathology of sickle cell anaemia in Jamaican adults over 30. Trans R Soc Trop Med Hyg 1969; 63: 102-11.

48. Nicholson GD. Post-streptococcal glomerulonephritis in adult Jamaicans with and without sickle cell anaemia. West Indian Med J 1977; 26: $78-84$.

49. Nicholson GD, Amin UF, Brooks SE, Alleyne GA. End-stage renal failure in sickle cell trait. West Indian Med J 1979; 28: 235-9.

50. Nicholson GD, Amin UF, Alleyne GA. Proteinuria and the nephrotic syndrome in homozygous sickle cell anaemia. West Indian Med J 1980; 29: $239-46$

51. Grell GA, Alleyne GA, Serjeant GR. Blood pressure in adults with homozygous sickle cell disease. Lancet 1981; 2: 1166.

52. Gray RH. Clinical features of homozygous SS disease in Jamaican children. West Indian Med J 1971; 20: 60-8.

53. Serjeant BE, Forbes M, Williams LL, Serjeant GR. Screening cord bloods for detection of sickle cell disease in Jamaica. Clin Chem 1974; 20: 666-9.

54. Serjeant GR, Serjeant BE, Forbes M, Hayes RJ, Higgs DR, Lehmann H. Haemoglobin gene frequencies in the Jamaican population: a study in 100000 newborns. Br J Haematol 1986; 64: 253-62.

55. John AB, Ramlal A, Jackson H, Maude GH, Waight-Sharma A, Serjeant GR. Prevention of pneumococcal infection in children with homozygous sickle cell disease. Br Med J 1984; 288: 1567-70.

56. Emond AM, Collis R, Darvill D, Higgs DR, Maude GH, Serjeant GR Acute splenic sequestration in homozygous sickle cell disease: natural history and management. J Pediatr 1985; 107: 201-6.

57. Serjeant GR, Topley JM, Mason K, Serjeant BE, Pattison JR, Jones SE et al. Outbreak of aplastic crises in sickle cell anaemia associated with parvovirus-like agent. Lancet 1981; 2: 595-7. 
58. Goldstein AR, Anderson MJ, Serjeant GR. Parvovirus associated aplastic crisis in homozygous sickle cell disease. Arch Dis Child 1987; 62: 585-8.

59. Serjeant GR, Serjeant BE, Thomas P, Anderson MJ, Patou G, Pattison JR. Human parvovirus infection in homozygous sickle cell disease. Lancet 1993; 341: 1237-40.

60. Serjeant BE, Hambleton IR, Kerr S, Kilty CG, Serjeant GR. Haematological response to parvovirus B19 infection in sickle-cell disease. Lancet 2001; 358: 1779-80.

61. Gueri M, Gueri MV, Serjeant GR. The sickle cell trait and leg ulceration. J Trop Med Hyg 1972; 75: 193-4.

62. Serjeant GR. Leg ulceration in sickle cell anemia. Arch Intern Med 1974; 133: 690-4.

63. Gueri M, Van Devanter S, Serjeant BE, Serjeant GR. Oral zinc sulphate treatment of chronic non-sickle cell ulcers in Jamaica. West Indian Med J 1975; 24: 26-9.

64. Baum KF, MacFarlane DE, Cupidore L, Serjeant GR. Corynebacterium diphtheriae in sickle cell leg ulcers in Jamaica. West Indian Med J 1985; 34: 24-8.

65. Baum KF, MacFarlane DE, Maude GH, Serjeant GR. Topical antibiotics in chronic sickle cell leg ulcers. Trans R Soc Trop Med Hyg 1987; 81: 847-9.

66. Serjeant GR, Hambleton I. Priapism in homozygous sickle cell disease: a 40 year study of the natural history. West Indian Med J 2015; 64: 175-80.

67. Serjeant GR, de Ceulaer K, Maude GH. Stilboestrol and stuttering priapism in homozygous sickle cell disease. Lancet 1985; 11: 1274-6.

68. Douglas L, Fletcher H, Serjeant GR. Penile prostheses in the management of impotence in sickle cell disease. Br J Urol 1990; 65: 533-5.

69. Readett DR, Morris J, Serjeant GR. Determinants of nocturnal enuresis in homozygous sickle cell disease. Arch Dis Child 1990; 65: 615-8.

70. Readett DR, Morris JS, Serjeant GR. Nocturnal enuresis in sickle cell haemoglobinopathies. Arch Dis Child 1990; 65: 290-3.

71. Readett DR, Bamigbade T, Serjeant GR. Nocturnal enuresis in normal Jamaican children - implications for therapy. West Indian Med J 1991; 40: $181-4$

72. Poddar D, Maude GH, Plant MJ, Scorer H, Serjeant GR. Pregnancy in Jamaican women with homozygous sickle cell disease. Fetal and maternal outcome. Br J Obstet Gynaecol 1986; 93: 727-32.

73. Serjeant GR. Sickle haemoglobin and pregnancy. Br Med J 1983; 287: 628-30.

74. Dunn DT, Poddar D, Serjeant BE, Serjeant GR. Fetal haemoglobin and pregnancy in homozygous sickle cell disease. Br J Haematol 1989; 72: 434-8.

75. Morris JS, Dunn DT, Poddar D, Serjeant GR. Haematological risk factors for pregnancy outcome in Jamaican women with homozygous sickle cell disease. Br J Obstet Gynaecol 1994; 101: 770-3.

76. Serjeant GR, Look Loy L, Crowther M, Hambleton IR, Thame M. The outcome of pregnancy in homozygous sickle cell disease. Obstet Gynecol 2004; 103: 1278-85.

77. Serjeant GR, Hambleton IR, Thame M. Fecundity and pregnancy outcome in a cohort with sickle cell-haemoglobin C (SC) disease followed from birth. Br J Obstet Gynaecol 2005; 112: 1308-14.

78. Thame M, Lewis J, Hambleton IR, Trotman H, Serjeant G. Pattern of pregnancy weight gain in homozygous sickle cell disease and effect on birth size. West Indian Med J 2011; 60: 36-40.

79. Thame M, Singh-Minott I, Osmond C, Melbourne-Chambers R, Serjeant GR. Pregnancy in sickle cell-haemoglobin C (SC) disease. A retrospective study of birth size and maternal weight gain. Eur J Obstet Gynecol Reprod Biol 2016; 203: 16-9.

80. Redwood AM, Williams EM, Desal P, Serjeant GR. Climate and painful crisis of sickle-cell disease in Jamaica. Br Med J 1976; 1: 66-8.

81. Baum KF, Dunn DT, Maude GH, Serjeant GR. The painful crisis of homozygous sickle cell disease: a study of risk factors. Arch Int Med 1987; 147: 1231-4.

82. Serjeant GR, Chalmers RM. Current concerns in haematology. 1. Is the painful crisis of sickle cell disease a 'steal' syndrome? J Clin Pathol 1990; 43: 789-91.
83. Serjeant GR, De Ceulaer C, Lethbridge R, Morris JS, Singhal A, Thomas PW. The painful crisis of homozygous sickle cell disease - clinical features. Br J Haematol 1994; 87: 586-91.

84. Mohan JS, Marshall JM, Reid HL, Thomas PW, Serjeant GR. Peripheral vascular response to mild indirect cooling in patients with homozygous sickle cell (SS) disease and the frequency of painful crisis. Clin Sci 1998; 94: 111-20.

85. Serjeant GR, Serjeant BE. A comparison of erythrocyte characteristics in sickle cell syndromes in Jamaica. Br J Haematol 1972; 23: 205-13.

86. Millard DP, Mason K, Serjeant BE, Serjeant GR. Comparison of haematological features of the beta ${ }^{\circ}$ and beta $^{+}$thalassaemia traits in Jamaican Negroes. Br J Haematol 1977; 36: 161-70.

87. Serjeant BE, Mason KP, Serjeant GR. The development of haemoglobin $\mathrm{A}_{2}$ in normal Negro infants and in sickle cell disease. Br J Haematol 1978; 39: 259-65.

88. Serjeant GR, Grandison Y, Mason K, Serjeant B, Sewell A, Vaidya S. Haematological indices in normal Negro children: a Jamaican cohort from birth to five years. Clin Lab Haematol 1980; 2: 169-78.

89. Stevens MC, Maude GH, Beckford M, Grandison Y, Mason K, Serjeant $\mathrm{BE}$ et al. Haematological change in sickle cell-haemoglobin $\mathrm{C}$ disease and in sickle cell-beta thalassaemia: a cohort study from birth. $\mathrm{Br} \mathrm{J}$ Haematol 1985; 60: 279-92.

90. Hayes RJ, Beckford M, Grandison Y, Mason K, Serjeant BE, Serjeant GR. The haematology of steady state homozygous sickle cell disease: frequency distributions, variation with age and sex, longitudinal observations. Br J Haematol 1985; 59: 369-82.

91. Maude GH, Hayes RJ, Serjeant GR. The haematology of steady state homozygous sickle cell disease: interrelationships between haematological indices. Br J Haematol 1987; 66: 549-58.

92. Rogers DW, Clarke JM, Cupidore L, Ramlal AM, Sparke BR, Serjeant GR. Early deaths in Jamaican children with sickle cell disease. Br Med J 1978; 1: 1515-6.

93. Thomas AN, Pattison C, Serjeant GR. Causes of death in sickle-cell disease in Jamaica. Br Med J (Clin Res Ed) 1982; 285: 633-5.

94. Higgs DR, Pressley L, Old JM, Hunt DM, Clegg JB, Weatherall DJ et al. Negro alpha-thalassaemia is caused by the deletion of a single alphaglobin gene. Lancet 1979; 2: 272-6.

95. Higgs DR, Pressley L, Clegg JB, Weatherall DJ, Higgs S, Carey P et al. Detection of alpha thalassaemia in Negro infants. Br J Haematol 1980; 46: $39-46$.

96. Serjeant GR, Mason KP, Serjeant BE. Negro alpha-thalassaemia: genetic studies in homozygous sickle cell disease. J Med Genet 1980; 17: 281-4.

97. Higgs DR, Pressley L, Serjeant GR, Clegg JB, Weatherall DJ. The genetics and molecular basis of alpha thalassaemia in association with HbS in Jamaican Negroes. Br J Haematol 1981; 47: 43-56.

98. Wainscoat JS, Thein SL, Higgs DR, Bell JI, Weatherall DJ, Al-Awamy $\mathrm{BH}$ et al. A genetic marker for elevated levels of haemoglobin $\mathrm{F}$ in homozygous sickle cell disease? Br J Haematol 1985; 60: 261-8.

99. Noguchi CT, Dover GJ, Rodgers GP, Serjeant GR, Antonarakis SE, Anagnou NP et al. Alpha-thalassemia changes erythrocyte heterogeneity in sickle cell disease. J Clin Invest 1985; 75: 1632-7.

100. Stevens MC, Maude GH, Beckford M, Grandison Y, Mason K, Taylor B et al. Alpha thalassemia and the hematology of homozygous sickle cell disease in childhood. Blood 1986; 67: 411-4.

101. Vyas P, Higgs DR, Weatherall DJ, Dunn D, Serjeant BE, Serjeant GR. The interaction of alpha thalassaemia and sickle cell-beta zero thalassaemia. Br J Haematol 1988; 70: 449-54.

102. Higgs DR, Aldridge BE, Lamb J, Clegg JB, Weatherall DJ, Hayes RJ et al. The interaction of alpha-thalassemia and homozygous sickle-cell disease. N Engl J Med 1982; 306: 1441-6.

103. Boyer SH, Dover GJ, Serjeant GR, Smith KD, Antonarakis SE, Embury $\mathrm{SH}$ et al. Production of $\mathrm{F}$ cells in sickle cell anemia: regulation by a genetic locus or loci separate from the beta-globin gene cluster. Blood 1984; 64: 1053-8.

104. Antonarakis SE, Boehm CD, Serjeant GR, Theisen CE, Dover GJ, Kazazian HH Jr. Origin of the beta S-globin gene in blacks: the contribution of recurrent mutation or gene conversion or both. Proc Natl Acad Sci USA 1984; 8: 853-6. 
105. Kulozik AE, Wainscoat JS, Serjeant GR, Kar BC, Al-Awamy B, Esan $F$ et al. Geographical survey of $\beta S$-globin gene haplotypes: evidence for an independent Asian origin of the sickle-cell mutation. Am J Hum Genet 1986; 39: 239-44.

106. Kulozik AE, Kar BC, Satapathy RK, Serjeant BE, Serjeant GR, Weatherall DJ. Fetal hemoglobin levels and beta(s) globin haplotypes in an Indian population with sickle cell disease. Blood 1987; 69: 1742-6.

107. Chang YC, Smith KD, Moore RD, Serjeant GR, Dover GJ. An analysis of fetal hemoglobin variation in sickle cell disease: the relative contributions of the X-linked factor, beta-globin haplotypes, alpha-globin gene number, gender and age. Blood 1995; 85: 1111-7.

108. Talbot JF, Bird AC, Serjeant GR, Hayes RJ. Sickle cell retinopathy in young children in Jamaica. Br J Ophthalmol 1982; 66: 149-54.

109. Talbot JF, Bird AC, Rabb LM, Maude GH, Serjeant GR. Sickle cell retinopathy in Jamaican children - a search for prognostic factors. Br J Ophthalmol 1983; 67: 782-5.

110. Talbot JF, Bird AC, Maude GH, Acheson RW, Moriarty BJ, Serjeant GR Sickle cell retinopathy in Jamaican children: further observations from a cohort study. Br J Ophthalmol 1988; 72: 727-32.

111. Penman AD, Talbot JF, Chuang EL, Thomas P, Serjeant GR, Bird AC. A new classification of peripheral retinal vascular changes in sickle cell disease. Br J Ophthalmol 1994; 78: 681-9.

112. Downes SM, Hambleton IR, Chuang EL, Serjeant GR, Bird AC. Incidence and natural history of proliferative sickle retinopathy: observations from a cohort study. Ophthalmology 2005; 112: 1869-75.

113. Walker TM, Serjeant GR. Focal echogenic lesions in the spleen in sickle cell disease. Clin Radiol 1993; 47: 114-6.

114. Walker TM, Serjeant GR. Increased renal reflectivity in sickle cell disease: prevalence and characteristics. Clin Radiol 1995; 50: 566-9.

115. Walker TM, Serjeant GR. Biliary sludge in sickle cell disease. J Pediatr 1996; 129: 443-5.

116. Walker TM, Beardsall K, Thomas PW, Serjeant GR. Renal length in sickle cell disease: observations from a cohort study. Clin Radiol 1996; 46: $384-8$.

117. Walker TM, Hambleton IR, Serjeant GR. Gallstones in sickle cell disease: observations from the Jamaican Cohort Study. J Pediatr 2000; 136: $80-5$.
118. Haverfield EV, McKenzie CA, Forrester T, Bouzekri N, Harding R, Serjeant GR et al. UGT1A1 variation and gallstone formation in sickle cell disease. Blood 2005; 105: 968-72.

119. Christakis J, Vavatsi N, Hassapopoulou H, Papadopoulou M, Mandraveli $\mathrm{K}$, Loukopoulos D et al. Comparison of homozygous sickle cell disease in northern Greece and Jamaica. Lancet 1990; 335: 637-40.

120. Serjeant GR. The challenge of sickle cell disease in Saudi Arabia. Ann Saudi Med 1990; 10: 443-8.

121. Padmos MA, Roberts GT, Sackey K, Kulozik A, Bail S, Morris JS et al. Two different forms of homozygous sickle cell disease occur in Saudi Arabia. Br J Haematol 1991; 79: 93-8.

122. Serjeant GR. The geography of sickle cell disease: opportunities for understanding its diversity. Ann Saudi Med 1994; 14: 237-46.

123. Serjeant GR, Ndugwa CM. Sickle cell disease in Uganda: a time for action. E Afr Med J 2003; 80: 384-7.

124. Ndugwa C, Higgs D, Hambleton I, Mason K, Serjeant BE, Serjeant GR. Homozygous sickle cell disease in Uganda and Jamaica. A comparison of Bantu and Benin haplotypes. West Indian Med J 2012; 61: 684-91.

125. Patel J, Patel B, Gamit N, Serjeant GR. Screening for the sickle cell gene in Gujarat, India: a village-based model. J Community Genet 2013; 4: 43-7.

126. Mehta V, Mistry A, Raicha B, Italia Y, Serjeant G. Transfusion in sickle cell disease: experience from a Gujarat centre. Indian J Pediatr 2014; 81: 234-7.

127. Patel J, Serjeant GR. Newborn screening for sickle cell disease in India: the need for defining optimal clinical care. Indian J Pediatr 2014; 81: 229-30.

128. Patra PK, Khodiar PK, Hambleton IR, Serjeant GR. The Chhattisgarh state screening programme for the sickle cell gene: a cost-effective approach to a public health problem. J Community Genet 2015; 6: $361-8$.

129. Serjeant GR. Evolving locally appropriate models of care. Ind J Med Res 2016; 143: 405-13.

130. Serjeant GR, Serjeant BE, Mason KP, Gibson F, Gardner R, Warren L et al. Voluntary premarital screening to prevent sickle cell disease in Jamaica: does it work? J Community Genet 2017; 8: 133-9. 